\title{
IMPLEMENTATION OF THE GREEN GOVERNANCE CONCEPT AND GREEN MANAGEMENT PRACTICES IN CORPORATIONS OF EBRD REGIONS - SELECTED ISSUES
}

\author{
Katarzyna ŻAK \\ University of Economics, Katowice; katarzyna.zak@ue.katowice.pl, ORCID: 0000-0002-9212-7206
}

\begin{abstract}
Purpose: The purpose of the paper is to identify the level of involvement of the corporations of the EBRD regions in the implementation of the concept of sustainable development, and to evaluate the applied solutions in the field of green management.

Design/methodology/approach: The research methods used in the paper include the review of Polish and foreign literature, and the analysis of data from secondary sources. The desk research analysis was conducted on the basis of numerical information contained in the publication entitled "Transition Report 2019-20" and presented on the website of The European Bank for Reconstruction and Development (EBRD).
\end{abstract}

Findings: The result of the conducted research include the indication of the corporations in the countries of the EBRD regions that are leaders in the field of green governance and green management, and identification of factors and the extent to which they have an impact on the implementation of sustainable development postulates.

Research limitations/implications: The presented findings encourage further research to determine the causes of drastic differences in the field of green governance and green management in the studied corporations of the EBRD regions and the possibility of limiting them.

Practical implications: The analysis and evaluation of the implementation of the main practices of green management in the corporations of the EBRD regions allow to identify leaders in this area and apply the model of their operation (benchmarking) to improve the position of the organizations that show deficits.

Social implications: The use of the presented data, analyses and conclusions should imply further actions and strategies in enterprises necessary to implement the concept of sustainable development.

Originality/value: The paper synthetically presents the significance of the concept of green governance and the application of green management practices by corporations from the EBRD regions.

Keywords: green governance, green management, environment, sustainable development.

Category of the paper: General review. 


\section{Introduction}

Over the years, the issues of sustainable development of enterprises and corporate governance have been developing separately. The first referred to the expectations and postulates of stakeholders and emphasized the importance of social and environmental dimension of the company's operation. The other focused on shareholders' goals and was based on the paradigm of maximization of the value for shareholders and protection of the interests of investors. In recent years, however, the integration of these two approaches has been observed. It leads to the development and broadening of the perception of the role of enterprises in the economy and society, and integrates the financial, social, and environmental dimensions of its functioning. This resulted in a new approach to the concept of corporate governance and company management. Environmental issues are increasingly more emphasized in both of them.

It should be noted that the integration of the concept of sustainable development, corporate governance and corporate management has specific implications, which mainly include, (Kirkpatrick, 2009):

- Boards (supervisory boards, boards of directors) are expected to incorporate a wider perspective for evaluating company performance and incorporate both shareholder and stakeholder expectations.

- Companies are expected to provide both reporting to shareholders (interested mostly in the financial statements) and at the same time disclosing information of their social and environmental performance. Integrated reporting is supposed to deliver a bigger picture of the company activity and encourage companies to combine the incorporation of shareholder and stakeholder expectations.

- Executive compensation should be structured adequately to combine social, environmental, and financial performance measure to become an incentive for managers to have a more integrated approach to company purpose.

The purpose of the paper is to identify the level of involvement of the corporations of the EBRD regions in the implementation of the concept of sustainable development, and to evaluate the solutions applied in the field of green management.

The paper uses such research methods as the review of Polish and foreign literature and the analysis of data from secondary sources. The desk research analysis was conducted on the basis of the numerical information contained in the publication entitled "Transition Report 2019-20" and presented on the website of The European Bank for Reconstruction and Development (EBRD). 


\section{Environment as the major priority}

Brundtland Commission Report entitled "Our Common Future" that was published in the second half of the 1980s, is often seen as a turning point in the perception of the relationship between human activity and the natural environment. It was then that the term sustainable development appeared. More than 30 years have passed since then, and it seems that there has been a growing awareness of the fact that it is necessary to take both political, economic and social actions, maintaining the natural balance and durability of basic natural processes, in order to guarantee the possibility of satisfying basic needs of individual communities or citizens of both the present generation and future generations (Dz.U. [Journal of Laws], 2019).

The importance of this issue is also proved by the annually published data contained in "The Global Risk Report". Already in 2007, it was indicated that the most important global threats, in terms of the probability of their occurrence and impact, were primarily technological, societal, and economic in nature. As Table 1 shows, environmental threats have also been apparent for some time, but now they completely dominate the list. 2011 was the breakthrough year, when four global threats, i.e. storms and cyclones, flooding, biodiversity loss and climate changes were identified for the first time as the most important to the environment. On the other hand, in 2020, all the top five global threats in terms of the probability of their occurrence concerned the issues related to the environment. In addition, the report identifies three environmental issues among the top five threats that may have the greatest impact if not addressed. The lack of effects in terms of adverse climate changes is the most important of them, but the loss of biodiversity and the occurrence of extreme weather conditions are also mentioned (The Global Risk Report, 2020).

Table 1.

Review of the main global threats in selected years

\begin{tabular}{|c|c|c|c|}
\hline 2007 & 2011 & 2016 & 2020 \\
\hline \multicolumn{4}{|c|}{ Top 5 Global Risks in Terms of Likelihood } \\
\hline Infrastructure breakdown & Storms and cyclones & Involuntary migration & Extreme weather \\
\hline Chronic diseases & Flooding & Extreme Feather & Climate action failure \\
\hline Oil price shock & Corruption & Climate action failure & Natural disasters \\
\hline China hard landing & Biodiversity loss & Interstate conflict & Biodiversity loss \\
\hline Blow up in asset prices & Climate change & Natural catastrophes & $\begin{array}{l}\text { Human-made } \\
\text { environmental } \\
\text { disasters }\end{array}$ \\
\hline \multicolumn{4}{|c|}{ Top 5 Global Risks in Terms of Impact } \\
\hline Blow up in asset prices & Fiscal crises & Climate action failure & $\begin{array}{l}\text { Climate action } \\
\text { failure }\end{array}$ \\
\hline Deglobalization & Climate change & $\begin{array}{l}\text { Weapons of mass } \\
\text { destruction }\end{array}$ & $\begin{array}{l}\text { Weapons of mass } \\
\text { destruction }\end{array}$ \\
\hline Interstate and civil wars & Geopolitical conflict & Water crises & Biodiversity loss \\
\hline Pandemics & Asset price collapse & Involuntary migration & Extreme weather \\
\hline Oil price shock & Energy price volatility & Energy price shock & Water crises \\
\hline
\end{tabular}

Adapted from (The Global Risk Report, 2020). 


\section{From governance and management to green governance and green management}

In view of the presented threats, the need for an appropriate response from various environments, including the business community must occur. Thus, it seems that the concept of sustainable development is most topical and adequate. Many theoretical studies and a number of research works have already been performed on the subject. Generally speaking, the idea of balanced and sustainable development is based on the lasting coexistence of three elements: economy, society, and the environment. One of the definitions says that sustainable development is a process of social, economic and environmental changes that ensures a balance between profits and costs of development, in the perspective of future generations, i.e. it is "a reflection of the policy and strategy of continuous economic and social development with no harm to the environment and natural resources, the quality of which determines the continuation of human activity and further development" (Grudzewski et al., 2010). For an individual company, this means that the basic assumption of its development is the combination of traditional goals of activity, such as development, value growth and long-term profits, with conscious activities aimed at observing the basic economic, social, and environmental principles (Żak, 2015). It should be realised that it is not easy to reconcile such diverse and different priorities. Implementation of the concept of governance is a specific solution that allows to reconcile and balance the selfish goals of the business environment with the requirements of social and ecological circles.

Numerous publications define this concept in various ways, which results both from the adopted cognitive perspective and its context. D. Crowther and S. Seifi (2011) consider the concept of governance from the level of state, and define it as exercising political power and using institutional resources to manage the problems of the society and its affairs. Jones, Hesterly and Borgatti (1997) focus on informal regulatory systems, the so-called network governance. There are no formal rules within it - they are not legally binding. Instead, there are social obligations and governance within the network. In this sense, governance is perceived as a reflective process of self-organization of independent entities involved in complex relations of interdependence for the purpose of implementation of mutually beneficial ventures and proper management of conflicts arising during interactions (Crowther and Seifi, 2011).

The concept of corporate governance (CG) is used in the context of functioning of enterprises. In a general sense it is the system of corporate management and control (BogaczMiętka, 2011). It is worth noting here that in the literature on the subject there are numerous definitions of corporate governance that distinguish its narrow and broad approach. In the first meaning, corporate governance refers to the Anglo-Saxon system, in which its aim is to create solutions so that in the conditions of a dichotomous ownership and control system, the managers act in the interests of shareholders, i.e. the company owners (Shleifer and Vishny, 1997). In a broad approach to this notion, not only managers and owners are noticed, but also other parties interested in the functioning of the corporation, i.e. a wide range of stakeholders. 
Currently, more and more economists and other circles opt for adopting a broad definition of CG (Schwerk, 2008). In this approach, according to OECD (2015) corporate governance involves a set of relationships between a company's management, its board, its shareholders and other stakeholders. Corporate governance also provides the structure through which the objectives of the company are set, and the means of attaining those objectives and monitoring performance are determined. On the other hand, another EU document entitled "Green Paper" (2011) defines corporate governance as the system by which companies are directed and controlled and as a set of relationships between a company's management, its board, its shareholders and its other stakeholders. Li et al. (2016) emphasize that the modern understanding of this notion is characterized by the following features:

- Governance is based on coordination rather than control.

- Governance involves many stakeholders related to each other and representing private and public sectors among others, as well as business organizations.

- Governance emphasizes the balance of interests and goals, as well as participation in decision making.

- Governance is a continuous interaction and aims at maintaining the continuity of the relationships.

The concept of corporate governance is inseparably connected with the notion of corporate management. While corporate governance refers to the rules and procedures implemented to ensure that the company operates in accordance with law and for the optimal benefit of all stakeholders, corporate management refers to the techniques applied by the management to help the company operate and grow. The difference between governance and management is that management takes care of the day to day and is task-oriented. Governance, on the other hand, looks at the bigger picture and is strategy-oriented.

Giving high priority to environmental issues in human activity in a new approach to economy and business management often results in the occurrence of the notion of "green". Green is a symbol of life and the colour of nature that often represents the relationship between humanity and nature. Hence, such terms as green economy, green growth, green corporation, green management, green governance, or other related terms are more and more often used. In the literature on the subject, the concept of green governance is defined as sustainable development. Post et al. (2011) claimed that green governance is a long-term economic, social, and environmental sustainability. On the other hand one of the studies on green management defined this term as practices that produce environmentally-friendly products and minimize the impact on the environment through green production, green research and development, and green marketing $\|$ (Peng and Lin, 2008). On the other hand, Y. Loknath and B.A. Azeem (2017) show that green management is the organization-wide process of applying innovation to achieve sustainability, waste reduction, social responsibility, and a competitive advantage via continuous learning and development and by embracing environmental goals and strategies that are fully integrated with the goals and strategies of the organization. 


\section{Synthetic diagnosis of the application of selected firms' green management practices in the countries of the EBRD regions}

Assessing the implementation of green governance requires access to a number of documents describing the ability of corporations to deal with environmental issues. However, information on the application of such practices by enterprises is often available only for listed companies that declare the implementation of the CSR (corporate social responsibility) policy. Therefore, this gap may be partially filled with the latest data on 7,294 corporations from EBRD regions, i.e. the countries of Central Europe and the Baltic states (Croatia, Estonia, Hungary, Latvia, Lithuania, Poland, Slovak Rep., Slovenia), South - eastern Europe (Albania, Bosnia and Hercegovina, Bulgaria, Cyprus, Greece, Kosovo, Montenegro, North Macedonia, Romania, Serbia), Eastern Europe and the Caucasus (Armenia, Azerbaijan, Belarus, Georgia, Moldavia, Ukraine), Central Asia (Kazakhstan, Kyrgyz Rep., Mongolia, Tajikistan, Turkmenistan, Uzbekistan), Southern and eastern Mediterranean (Egypt, Jordan, Lebanon, Morocco, Tunisia, West Bank Gaza) as well as Russia and Turkey presented by EBRD, the EIB and the World Bank Group (Transition Report 2019-20, 2020).

The average overall rating of firms' green management in the EBRD countries in 2019 was 5.53, but it differed for individual EBRD regions. Central Asia had the lowest value (4.76). Southern and eastern Mediterranean as well as South-eastern Europe were also below the average with the values of 5.17 and 5.42, respectively. On the other hand, the Eastern Europe and the Caucasus region obtained a value identical to the average value for all EBRD countries, and only the Central Europe region and the Baltic states region achieved a value higher than the average, i.e. 6.62. The overall results of firm's green management in individual EBRD countries in 2019 are presented in Fig. 1.

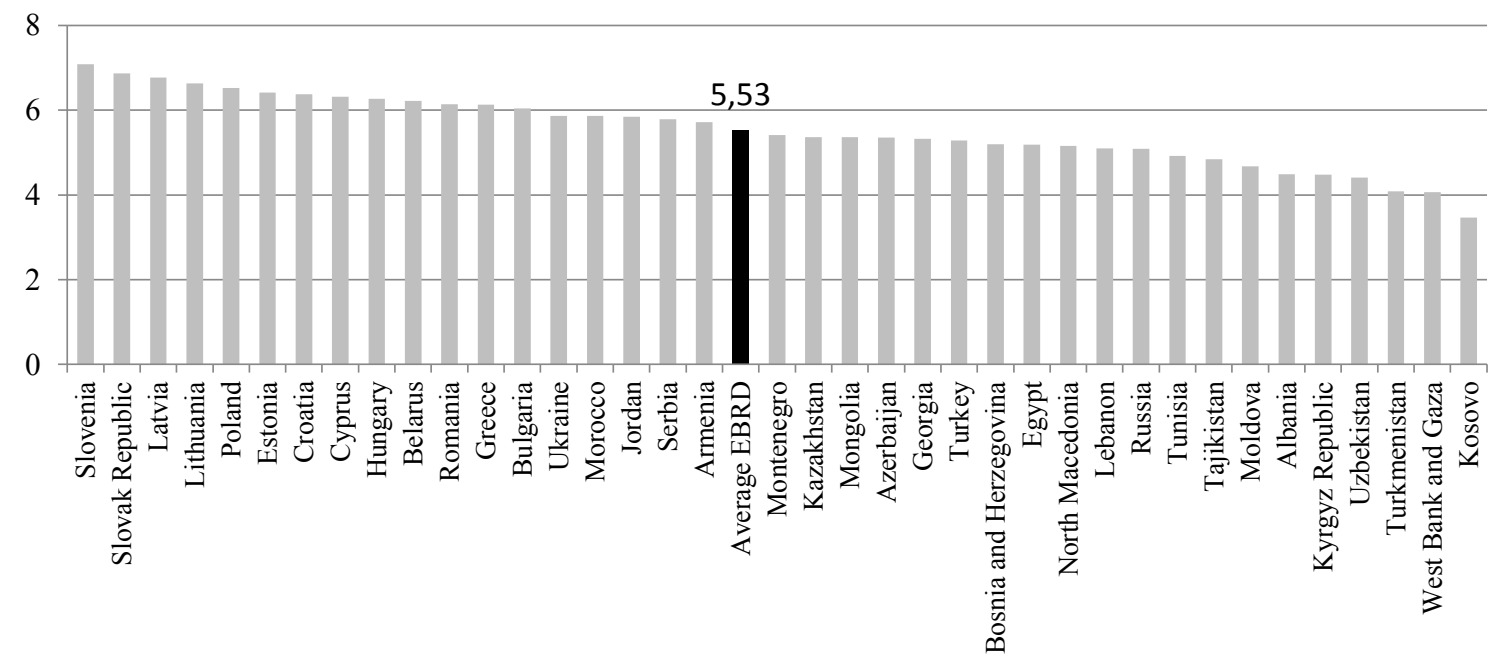

Figure 1. General results of the application of firm's green management in the EBRD countries in 2019. Adapted from (Transition Report 2019-20, 2020, p. 112). 
The intensity with which companies have been paying attention to environmental issues in recent years suggests that there is a clear relationship between the quality of firms' general management and the quality of green management. Meanwhile, the conducted research showed that the average value of the correlation coefficient between them is positive, but quite low and teaches only 0.23 . The leaders for which the correlation coefficient significantly exceeds the value of 0.23 are companies from the countries such as Latvia, Greece, Slovenia, North Macedonia, and Croatia. Corporations from such countries as: Tajikistan, Jordan, Kosovo, Lebanon, Georgia West Bank and Gaza and Turkey perform poorly in this respect (Transition Report 2019-20, 2020). Meanwhile, the conducted research showed that the average value of the correlation coefficient between them is admittedly positive, but quite low, and reaches only 0.23 . The leaders for which the correlation coefficient significantly exceeds the value of 0.23 are companies from such countries as Latvia, Greece, Slovenia, North Macedonia, and Croatia. Corporations from such countries as: Tajikistan, Jordan, Kosovo, Lebanon, Georgia West Bank and Gaza and Turkey rank poorly in this respect (Transition Report 2019-20, 2020).

A detailed analysis of the results of corporations from the above-mentioned regions comprises four main types of green enterprise management practices, i.e.:

- creation and implementation of strategies in the sphere of environment and climate change;

- clear definition of achievable environmental goals;

- hiring a manager with a clear mandate to deal with green issues;

- monitoring energy and water consumption as well as emissions of $\mathrm{CO}_{2}$ and other pollutants.

The obtained calculations confirm that there are clear differences between the EBRD regions not only in terms of overall results, but also within four main practices, i.e. (Transition Report 2019-20, 2020):

- From the point of view of creating and implementing strategies in the field of environment and climate change, companies from the Mediterranean basin, such as Portugal, Italy, Malta, and Spain, as well as from Central Europe and the Baltic countries perform the best - about $20 \%$ of them declare that they have such a strategy. Corporations from Turkey are at the opposite extreme, as only $7 \%$ of them take steps to build such a strategy.

- The situation is similar when it comes to defining achievable environmental goals. On average, around $18.3 \%$ of the surveyed enterprises in the EBRD regions had such goals. In this respect the companies in Central Europe and the Baltic States, as well as Portugal, Italy, Malta, and Spain perform the best. On the other hand, corporations from Turkey and the southern and eastern parts of the Mediterranean (Egypt, Jordan, Lebanon, Morocco) show large deficits in this field.

- Employing a manager responsible for environmental and climate change-related issues in the corporation is another important practice (Martin et al., 2012). On average, only $12.3 \%$ of the surveyed enterprises of the EBRD regions had an employee in such 
a position. Again, there are large discrepancies between corporations in different countries - from only $3 \%$ in Turkey to $28 \%$ in Slovenia. As a region, the countries of Western Europe (formerly EEC) as well as Central Europe and the Baltic states have the best achievements in this respect. In the latter, almost three-quarters of environmental managers in enterprises are directly subordinate to the firm's CEO, its board of directors or its owners, while in Russia only 18\%. Turkish corporations and the economies of the southern and eastern Mediterranean perform the worst in this area.

- In terms of monitoring energy and water consumption, as well as emission of $\mathrm{CO}_{2}$ and other pollutants, companies from Western Europe (France, Germany, Benelux countries, Denmark) are the clear leaders. And once again, Turkish corporations and the economies of the southern and eastern Mediterranean have to do a lot to catch up with others in this respect.

\section{The main drivers of the quality of firms' green management in the countries of EBRD regions}

Exercising effective and efficient governance over the implementation and execution of green corporate governance practices requires identifying the main determinants that shape them. Among many determinants, the most important include (Table 2): the size of the enterprise and the time of business operation on the market, the foreign entities' share in the ownership, the level of internationalization, listing on the stock exchange, customer pressure, own experience of companies related to the effects of extreme weather events or pollution, as well as regulations concerning environment protection, such as energy taxes or levies.

Table 2.

Determinants of the quality of firms' green management

\begin{tabular}{|l|c|c|}
\hline \multicolumn{1}{|c|}{ Drivers } & Correlation coefficient & Standard Error \\
\hline Customer pressure & 0.853 & 0.040 \\
\hline Energy tax/levy & 0.454 & 0.036 \\
\hline Monetary losses due to pollution caused by others & 0.335 & 0.110 \\
\hline 25\% or more foreign-owned & 0.219 & 0.044 \\
\hline Listed & 0.191 & 0.047 \\
\hline Monetary losses due to extreme weather & 0.167 & 0.049 \\
\hline Direct exporter & 0.139 & 0.031 \\
\hline Large old firm & 0.138 & 0.041 \\
\hline Large young firm & 0.074 & 0.113 \\
\hline Old SME & -0.095 & 0.041 \\
\hline
\end{tabular}

Note: Estimated using ordinary least squares. Old firms are at least five years old; large firms have at least 100 employees.

Adapted from (Transition Report 2019-20, 2020, p. 86). 
Comparing the data presented in Table 2, it should be noted that external factors of customer pressure and being subject to an energy tax or levy are the two most important factors influencing the results in the field of ecological management. Customer pressure is a factor that has a major impact on the quality of green management in the enterprise. About one in seven companies operating in the EBRD regions confirm that their customers require environmental certifications or compliance with certain environmental standards as a condition for doing business. In each region, results in the sphere of green management are usually much higher for companies that have experienced such customer pressure than for those that have not experienced it. The strength of this influence is evidenced by estimates showing that the improvement in green management that is associated with facing customer pressure is almost four times the size of that associated with foreign ownership.

Another important external factor is environmental regulations, which can be proxied by energy taxes or levies. Where energy is expensive, firms have an incentive to use less of it. The resulting positive impact on the environment is especially large where energy is generated using fossil fuels. The estimates in table 2 suggest that firms which are subject to an energy tax or levy have substantially better green management practices than firms which are not. That effect is about twice the size of the impact of being under foreign ownership or listed on a stock exchange.

$10.3 \%$ of 7,294 corporations from the above-mentioned EBRD regions declare that they have experienced cash losses due to extreme weather events in the past three years. This concerns Moldova, North Macedonia, and Romania, which faced severe floods in 2016, while Croatia, Poland, Romania and Slovenia experienced severe hailstorms. In many of the analysed countries there were also heat waves and droughts during the summer months, which became almost a permanent phenomenon. It is therefore no surprise that many companies have taken steps to improve their environmental management practices in response to their losses. Corporations from Turkey are an exception. The same is true of the $2.4 \%$ of firms that report having experienced monetary losses as a result of pollution not caused by their own activities.

In general, foreign ownership often improves firm-level productivity by transferring cutting-edge technology, management practices and knowledge to acquired firms and encouraging product and process innovation. Indeed, multinationals tend to use more advanced technology and production methods than their domestic counterparts, which can improve environmental outcomes. At the same time, however, firms in polluting industries may also relocate to "pollution havens" (countries with less stringent environmental regulations) in response to costly regulations in their home countries, increasing pollution levels both in their host countries and globally (Brucal et al., 2019; Cai et al., 2016). Conducted analyses show that in the EBRD regions, enterprises in which foreign investors have a share of $25 \%$ or more, have, on average, higher ecological management results compared to enterprises in which the share is lower. 
Foreign ownership is not the only way in which firms can learn about state-of-the-art green management practices. They can also do so by competing in international markets - firms which export tend to have better green management than firms which do not.

Another factor stimulating green management is the question of whether the company is listed on the stock exchange. Public companies are usually subject to greater control and greater pressure from investors or stakeholders to inform about the issues related to environmental protection activities. It is worth mentioning here that in 2009, the Warsaw Stock Exchange launched the RESPECT index, which was replaced by the WIG-ESG index in 2019. It enables the selection of entities with the highest standards in environment, social and governance areas.

Regardless of the EBRD region, there is a relationship between the quality of green management in a company, its size, and the period of operation on the market. Large companies operating on market for a long time have, on average, better results in environmental management than those with shorter experience and belonging to the sector of small and medium-sized enterprises (SMEs). Meanwhile, the average green management scores of old SMEs are worse than those of young SMEs, and the average green management scores of large young firms are not significantly different from those of young SMEs.

\section{Conclusions}

Managers of enterprises and members of supervisory boards are increasingly more aware of the fact that in order to succeed in conditions of today's global competition, it is not enough to be economically competitive, but it is necessary to become more and more active in the areas that have not been of interest to most societies until recently. Identified requirements of the environment make corporations engage not only in strictly business ventures focused on economic goals, but also actively implement social and environmental projects. Thus, they implement the idea of sustainable development at the enterprise level and become a socially responsible organizations.

The presented data and analyses for the countries of the EBRD regions show that the level of corporate involvement in the concept of sustainable development and environmental issues is remarkably diverse and results from the impact of various stimuli. There are main conclusions:

- The quality of firms' green management, in the countries of the EBRD regions, is positively correlated with the average quality of general management practices (that is to say, firms' general approach to operations, monitoring, targets and incentives). This positive correlation is, however, relatively modest, with a coefficient of 0.23 . 
- The leaders for which the correlation coefficient significantly exceeds the value of 0.23 are companies from the countries such as Latvia, Greece, Slovenia, North Macedonia, and Croatia. Corporations from such countries as: Tajikistan, Jordan, Kosovo, Lebanon, Georgia West Bank and Gaza and Turkey perform poorly in this respect.

- There are several the main determinants that shape of the quality of firms' green management, that is customer pressure, energy tax/levy, monetary losses due to pollution caused by others and monetary losses due to extreme weather. Also foreignowned and listed firms have better green management practices, as do exporters.

- From the point of view of creating and implementing strategies in the field of environment and climate change, companies from the Mediterranean basin, as well as from Central Europe and the Baltic countries perform the best. Corporations from Turkey are at the opposite extreme.

- On average, around $18.3 \%$ of the surveyed enterprises in the EBRD regions had defining environmental goals. In this respect the companies in Central Europe and the Baltic States, as well as Portugal, Italy, Malta, and Spain perform the best. On the other hand, corporations from Turkey, Egypt, Jordan, Lebanon and Morocco show large deficits in this field.

- On average, only $12.3 \%$ of the surveyed enterprises of the EBRD regions had a manager responsible for environmental and climate change-change-related issues. As a region, the countries of Western Europe (formerly EEC) as well as Central Europe and the Baltic states have the best achievements in this respect. Turkish corporations and the economies of the southern and eastern Mediterranean perform the worst in this area.

- In terms of monitoring energy and water consumption, as well as emission of $\mathrm{CO}_{2}$ and other pollutants, companies from Western Europe (France, Germany, Benelux countries, Denmark) are the clear leaders. And once again, Turkish corporations and the economies of the southern and eastern Mediterranean have to do a lot to catch up with others in this respect.

Thus, on the one hand, it is possible to indicate organizations for which the principles of green corporate governance and the practical application of green management solutions are a priority and serve building a positive image and achieving a better competitive position. These corporations mainly come from Central Europe and the Baltic states and usually aspire to the operating standards set by companies from Western Europe. On the other hand, there are corporations with poor results that come from Central Asia (many of which are former USSR republics) and Southern and eastern Mediterranean, in which the concept of sustainable development and environmental issues are not a priority in business culture. 
Finally, it is worth adding that there are many critical opinions towards the new perception of the company. The postulate of taking into account the needs and expectations of various stakeholder groups in the company's operations caused a split among theoreticians and practitioners of management. This is because the question is asked whether creating value for shareholders is still the fundamental goal of the company's operation, or it should rather meet the needs of other interest groups. And if the second option is chosen, where is the limit of the company's responsibility? (Marcinkowska, 2006). While reflecting on the stakeholder approach, K. Kim at el. (2010), formulate another question: how to properly operationalize the company's activity in the new perspectives (social and environmental)? Distracting managers' attention to additional goals that are difficult to measure, often makes them ineffective when trying to serve many "masters" (Kim at el., 2010).

\section{References}

1. Bogacz-Miętka, O. (2011). Kompendium wiedzy o nadzorze $i$ kontroli nad przedsiębiorstwem [Compendium of knowledge about governance and control over a company], Warszawa: CeDeWu, p. 27.

2. Brucal, A., Javorcik, B., Love, I. (2019). Good for the environment, good for business: Foreign acquisitions and energy intensity. Journal of International Economics, vol. 121.

3. Cai, X., Lu, Y., Wu, M., Yu, L. (2016). Does environmental regulation drive away inbound foreign direct investment? Evidence from a quasi-natural experiment in China. Journal of Development Economics, Vol. 123, pp. 73-85.

4. Crowther, D., Seifi, S. (2011). Corporate Governance and International Business. Ventus Publishing Aps., pp. 10-11.

5. Green Paper (2011). The EU corporate governance framework. Brussels, 5.4.2011COM(2011) 164 final. p. 2.

6. Grudzewski, W.M., Hejduk, I.K., Sankowska, A., Wańtuchowicz, M. (2010). Sustainability $w$ biznesie, czyli przedsiębiorstwo przyszłości. Zmiany paradygmatów $i$ koncepcji zarzadzania [Sustainability in business, i.e. a company of the future. Change in paradigms and concepts of management]. Warszawa: Poltex, p. 271 and following.

7. Jones, C., Hesterly, W.S., Borgatti, S.P., General, A. (1997). Theory of Network Governance: Exchange Conditions and Social Mechanism. Academy of Management Review, no. 22, pp. 911-945.

8. Kim, K., Nofsinger, J., Mohr, D. (2010). Corporate Governance. New Jersey: Pearson Hall, p. 173.

9. Kirkpatrick, G. (2009). The Corporate Governance Lessons from the Financial Crisis, OECD, http://www.oecd.org/finance/financial-markets/42229620.pdf, 12.08.2020. 
10. Li, W.A., Li, Y.J., Shi, D. (2016). Theoretical research on supply chain governance: Concept, intention, and normative analysis framework. Nankai Business Review, No. 19, pp. 4-15.

11. Loknath, Y., Azeem, B.A. (2017). Green Management-Concept and Strategies. National Conference on Marketing and Sustainable Development, October 13-14, pp. 692-693.

12. Marcinkowska, M. (2006). Władztwo korporacyjne w kontekście społecznej odpowiedzialności przedsiębiorstwa [Corporate governance in the context of corporate social responsibility]. In: S. Rudolf (ed.), Tendencje zmian $w$ nadzorze korporacyjnym [Trends of changes in corporate governance (pp. 409-428). Łódź: Wydawnictwo UŁ.

13. Martin, R., Muüls, M., de Preux, L., Wagner, U. (2012). Anatomy of a paradox: Management practices, organizational structure and energy efficiency. Journal of Environmental Economics and Management, Vol. 63, pp. 208-223.

14. OECD (2015). G20/OECD Principles of Corporate Governance. Paris: OECD Publishing, p. 9, http://dx.doi.org/10.1787/9789264236882-en, 02.08.2020.

15. Peng, Y., Lin, S. (2008). Local Responsiveness Pressure, Subsidiary Resources, Green Management Adoption, and Subsidiaries‘ Performance: Evidence from Taiwanese Manufacturers. Journal of Business Ethics, 79(1/2), pp. 199-212.

16. Post, C., Rahman, N., Rubow, E. (2011). Green governance: Boards of directors' composition and environmental corporate social responsibility. Business and Society, 50(10), pp. 189-223.

17. Schwerk, A. (2008). Strategisches gesellschaftliches Engagementund gute Corporate Governance. In: H. Backhaus-Maul, Ch. Biedermann, S. Näahrlich, J. Polterauer (eds.), Corporate Citizenship in Deutschland, Bilanz und Perspektiven (pp. 121-145). Wiesbaden: VS Verlag für Sozialwissenschaften, GWV Fachverlage GmbH.

18. Shleifer, A., Vishny, R.W. (1997). A Survey of Corporate Governance. Journal of Finance, vol. 52, no. 2, pp. 737-783.

19. The Act of April 27, 2001, Environmental Protection Law (Dz.U. [Journal of Laws] of 2019, item 1396).

20. The Global Risk Report 2020. Geneva: World Economic Forum.

21. Transition Report 2019-20 (2020). Better Governance, Better Economies. London: European Bank for Reconstruction and Development, 18.08.2020.

22. Żak, K. (2015). Green economy - w drodze do nowego globalnego standardu biznesowego [Green economy - on the way to new, global business standard]. Studia Ekonomiczne, Zeszyty Naukowe Uniwersytetu Ekonomicznego w Katowicach, nr 226, p. 172. 